\begin{tabular}{lc}
\hline \multicolumn{1}{c}{ A N N A L E S } \\
UNIVERSITATIS MARIAE CURIE-SKŁODOWSKA \\
LUBLIN - POLONIA \\
VOL. XXVI, 1 & SECTIOK \\
\hline
\end{tabular}

\title{
Recenzje. Sprawozdania
}

Reviews. Reports

\begin{abstract}
Jan Ryszard Sielezin, Recenzja: Marcin Jakub Wichmanowski, Myśl polityczna Polskiego Stronnictwa Ludowego Piast 1913/14-1931, Wydawnictwo Uniwersytetu Marii Curie-Skłodowskiej, Lublin 2017, ss. 442
\end{abstract}

Recenzowana książka jest przedsięwzięciem badawczym nader ambitnym. Dotychczas nie ukazała się obszerniejsza praca dotycząca myśli politycznej PSL Piast, nie licząc drobnych przyczynków oraz wydanej w 1970 r. monografii autorstwa Józefa Ryszarda Szaflika nader lakonicznie omawiającej założenia ideowo-programowe tej partii [Szaflik 1970]. Już podjęcie się tego zadania świadczy o odwadze i pasji twórczej autora, zważywszy na ogromną ilość źródeł, jakie zostały wykorzystane: archiwalnych, dokumentów programowych, prasy ludowej, pamiętników, wspomnień, relacji działaczy ludowych, sprawozdań stenograficznych z posiedzeń parlamentu, aktów prawnych i literatury naukowej.

Choć przedsięwzięcie badawcze obejmuje cezurę czasową lat (1913/14-1931), to ilość dokumentów wytworzonych przez tę partię budzi zdumienie ze względu na charakterystyczne cechy i różnorodność źródeł, co pośrednio wskazuje na znaczny potencjał ideowo-polityczny i zamysł odegrania określonej roli w życiu politycznym państwa. Działalność PSL Piast, zważywszy na lidera Wincentego Witosa i znaczenie tej partii w życiu politycznym II Rzeczypospolitej oraz pragmatyczno-utylitarną dynamikę działalności związaną z bieżącymi wydarzeniami politycznymi, społecznymi i przemianami gospodarczymi w kraju, umożliwia potencjalnym badaczom szersze spojrzenie na założenia programowe tej partii. Zasadna wydaje się zatem możliwość ewentualnego porównania z innymi ugrupowaniami chłopskimi działającymi w tym okresie i nie tylko.

PSL Piast przechodził różne przemiany i fazy w działalności statutowej. Na kształt ideowo-polityczny partii oraz organizacyjny wpływ miały wydarzenia polityczne w Polsce: powstanie odrodzonego państwa, wojna 1920 r., zamach majowy, kryzys gospodarczy i konflikty personalne w partii, ostre polemiki dotyczące problematyki politycznej i secesje na przełomie 1927/1928, a także odsunięcie się od działalności politycznej wielu działaczy. Nie można pominąć innych jeszcze czynników, np. znaczenia tzw. „pragmatyki życia politycznego”, w tym wkładu ludowców w rozwój państwowości polskiej i konsolidacji całego społeczeństwa w sytuacjach 
przełomowych. Trzeba zatem zgodzić się z tezą autora, że ze względu na „złożoność programową definicyjną i aksjologiczną badanie myśli ideowo-politycznej w aspekcie zmienności programowej jest nader trudne" (s. 15).

Uwzględniając różnorodne trudności i pułapki analityczne, autor właściwie przeanalizował w kontekście pragmatyczno-utylitarnym podstawowe założenia programowe tej partii. Słusznie zauważył, że istotny wpływ na kształt ideowo-polityczny i organizacyjny partii miały różne czynniki, które jeszcze w okresie zaborów mogły w przyszłości sprzyjać lub hamować rozwój działalności statutowej lub ideowo-politycznej, np. zabór rosyjski czy Galicja.

W pracy naukowej zasadniczym elementem umożliwiającym rozwiązanie problemu badawczego jest odwołanie się do metodologii i wykorzystanie charakterystycznych metod badawczych oraz przestrzeganie zasad krytycznego myślenia logicznego ${ }^{1}$. Korzyści płynące ze znajomości logiki mogą być różnorodne. Łatwo można udowodnić, że badacz (niezależnie od wieku czy dorobku) myślący i piszący logicznie, a nie „bełkotliwie” w postmodernistycznej konwencji „modnych bzdur” powinien się uporać z kluczowymi problemami badawczymi [por. Sokal, Briemont 2004; Gajda 1992: 57-69; Wierciński 2004].

Autor właściwie posłużył się zarówno językiem naukowym, jak i metodologią. Usiłował raczej z pozytywnym skutkiem uporać się z kwestią fundamentalną - hipotezami badawczymi, które w zamyśle każdego badacza są warunkiem sine qua non rozpoczęcia badań. Można mieć wątpliwość, czy sformułowanie siedmiu hipotez (przy czym niektóre z nich mają postać tezy) było słuszne i zasadne, ale wobec zgromadzenia w toku kwerendy tak bogatych i różnorodnych źródeł na pewno nie było błędnym założeniem. Autor powinien zatem usystematyzować hipotezy pod względem gradacji problemowej i szczegółowej, wówczas łatwiej byłoby wykazać, które z nich okazały się przydatne oraz umożliwiłyby weryfikację podstawowych założeń badawczych.

Są różne sposoby tworzenia (urabiania) hipotez badawczych, np. a) wysnucie wniosku hipotetycznego z istniejących teorii, b) odkrywanie treści hipotezy przez uogólnienie zebranych w toku badań danych, np. statystycznych czy faktów ze źródeł bardzo różnych, c) wysnuwanie wniosków i korzystanie z umiejętności tworzenia własnych domysłów o różnym stopniu prawdopodobieństwa, ale przyjęcie tych założeń wymaga intuicji badawczej i krytycznego myślenia tak niezbędnego w nauce.

Aby poprawnie ustalić stopień prawdopodobieństwa danej hipotezy, którą należy wysnuć logicznie, m.in. z poprawnie zabranych danych, należy uzupełnić hipotezy pytaniami badawczymi. Myśl polityczna jest kategorią badawczą obejmującą różne zagadnienia: państwo, jego ustrój, pojęcie narodu, projektowane reformy gospodarcze, prawa i wolności obywatelskie, bezpieczeństwo państwa (wewnętrzne i zewnętrzne), a więc zagadnienia, które wymagają bardzo uważnej analizy niejednokrotnie porównawczej. Autor recenzowanej pracy starannie uporządkował „materię” źródeł, gdyż, jak się zdaje, miał świadomość, że tworząc hipotezy, może wypaczyć ich założenia. Definicje hipotez (zbyt szerokie lub płytkie) mogą spowodować, że badacz będzie pisał o „historii idei” czy dziejach „wyobrażeń lub poglądów”, a nie o myśli politycznej. Inspirujące mogą być refleksje metodologiczne Waldemara Parucha, który zwrócił uwagę na fakt, że nie tylko poglądy „twórcy”, ale też motywy oraz środki i metody działania mogą znajdować skomplikowane odbicie jej autora [Paruch 1999: 27-28].

1 Niezbędną lekturą pomocną w rozwiązaniu problemów logiczno-metodologicznych na poziomie konceptualizacji pracy naukowej może być rozprawa prof. Andrzeja Kisielewicza [2017]. 
Tych problemów autor raczej uniknął, choć mogą się pojawić u czytelników rozprawy wątpliwości². Na usprawiedliwienie autora można przytoczyć tezę M. Witza, że zamknięte pojęcia występują jedynie w logice i matematyce, a sformułowanie niektórych pojęć „w realną lub jakąkolwiek prawdziwą definicję jest twierdzeniem fałszywym" [Sielezin 2012: 11; Jevons 1936; Chwistek b.r.w.]. Autor recenzowanej rozprawy miał wedle wszelkiego prawdopodobieństwa świadomość, że podejmując realizację takiego przedsięwzięcia badawczego, znalazł się w trudnym położeniu. Nie zawsze jest zatem możliwe rozstrzygnięcie, czy pisać w konwencji historii idei, czy myśli politycznej.

W ujęciu koncepcyjnym praca została dobrze zakomponowana, choć możliwy był inny układ problemowy i inne rozłożenie kontekstów i podtekstów. Recenzowana praca składa się ze wstępu, sześciu rozdziałów, zakończenia, bibliografii uporządkowanej według zasad naukoznawstwa oraz nader pomocnych: wykazu skrótów, spisu tabel, streszczenia w języku angielskim i indeksu nazwisk.

Mam pewien niedosyt, że w rozprawie nie uwzględniono osobnego rozdziału dotyczącego kultury narodowej oraz roli i znaczenia kultury chłopskiej, zagadnień związanych z dostępem do oświaty, kultury i awansu społecznego, a także znaczenia szkolnictwa wyższego dla dalszej edukacji chłopów. Kwestie te zapewne pozwoliłyby komplementarnie spojrzeć na wizję państwa, narodu i projektowanych przez PSL Piast reform społecznych, zważywszy na fakt, że chłopi byli najliczniejszą grupą społeczną w II RP.

Nie mam zastrzeżeń do metodologii, jaką autor zastosował w praktyce. Deklarowane metody i techniki badawcze, np. technika analizy świadectw i śladów politycznych, czy analiza tekstów programowych i zgłaszanych koncepcji politycznych oraz analiza świadectw myśli politycznej wiążą się ściśle z metodami historycznymi i krytyką źródeł. Szkoda, że autor nie wymienił i nie uzasadnił, czy i w jakim zakresie metody historyczne (jest ich kilka) mogły być pomocne w krytyce źródeł, jakie zostały zgromadzone i wykorzystane w rozprawie ${ }^{3}$. Trudno analizować różne dokumenty programowe, stenogramy z posiedzeń Sejmu, wypowiedzi publicystyczne, epistolografię, wspomnienia, prasę czy pamiętniki, nie odwołując się do określonych metod badawczych, przy czym egzegeza w przypadku źródeł dziewiczych często nabiera określonego znaczenia [Dobrzański 1999].

Baza archiwalna i bibliograficzna, jaką zgromadził autor, budzi uznanie i podziw (s. 365415) i świadczy o dociekliwości, pracowitości i dobrym rozeznaniu w materiale źródłowym. Niewątpliwie można byłoby wskazać jeszcze kilka opracowań czy wspomnień, np. rozprawę Mieczysława Ciećwierza, Ruch ludowy na terenie woj. pomorskiego w latach 1926-1931, pamiętniki Stanisława Rymara, Katarzyny Balalowej, czy przejrzeć prasę, np. „Piast Wielkopolski”, a także uwzględnić kilka prac poświęconych myśli politycznej czy kwestię konfliktów społecznych ważnych w kontekście programu tej partii [Holzer 1974; Juchnowski, Sielezin 2013; Stankiewicz 1963]. Nie uważam jednak, że brak wspomnianych prac czy nieuwzględnienie w rozprawie innych tytułów wydawanych lokalnie gazet ludowych obniżyłyby ogólną wartość rozprawy, którą oceniam pozytywnie.

Autor wykorzystał w znacznym zakresie prasę, ale miał świadomość, że to źródło tendencyjne i należy skonfrontować wiedzę źródłową z gazet z innymi źródłami oraz wiedzą pozaźródłową. Niejednokrotnie oparcie się na prasie jako podstawowym źródle informacji skutkuje

2 O trudnościach i przeszkodach związanych z definiowaniem zob. Pawłowski [1978]; Such [1975].

Szerzej o metodach: Topolski [1984]. 
niebezpieczeństwami. Prasa cytuje nie zawsze dokładnie, np. mowy polityków, i nie zawsze jest możliwe na jej podstawie ustalenie dokładnych dat tych mów czy przemówień. Mogą mieć one znaczenie zwłaszcza, gdy literalnie opisujemy jakiś fakt.

Praca zawiera bogatą faktografię, która świadczy o dociekliwości autora i umiejętnym poruszaniu się w złożonej materii faktograficznej, która jest niekiedy wieloznaczna [Sielezin 2018: 97-129]. Autor miał zapewne świadomość, że niektóre zagadnienia czy terminy są dyskusyjne, a nawet wieloznaczne. Przykładowo, odwołując się do bogatej literatury przedwojennej, wskazał na agraryzm. Może należało wspomnieć, że agraryzm w II RP to nie tylko idea, ale też „światopogląd wypływający z tej doktryny” [Żabko-Potopowicz 1935; 1937: 41].

Niektóre rozdziały mają znaczenie problemowe, inne zaś opisowo-sprawozdawcze, ale nie zawsze jest to postać jednoznaczna. Przykładowo rozdział II dotyczący struktury i potencjału organizacyjnego PSL Piast, w którym zawarta faktografia jest bardzo przejrzysta, dokładnie porządkuje omawiane zagadnienia i nadaje czytelne znaczenie. Wartość dodaną posiada niewątpliwie krótki podrozdział rozdziału II poświęcony organom prasowym stronnictwa. Szkoda tylko, że autor (nie licząc drobnych wzmianek) raczej pominął dzieje prasy Piasta po 1926 r. Ważnym uzupełnieniem (nie tylko faktograficznym) jest podrozdział Sojusznicy, przeciwnicy i wrogowie polityczni, który bardzo wymownie porządkuje relacje PSL Piast z innymi partiami rywalizującymi o wpływy na wsi. Jak słusznie zauważył autor, relacje PSL Piast z innymi partiami były determinowane „układami parlamentarnymi” (s. 120), co wskazywałoby na pragmatyczne podejście do polityki.

Kluczowe znaczenie w rozprawie zajmuje rozdział III Ustrój państwa, gdyż dotyczy określonych kategorii badawczych o charakterze programowym i ideowo-politycznym: suweren, władza ustawodawcza, organy wykonawcze, wymiar sprawiedliwości, samorząd. Podrozdziały są zatytułowane lakonicznie niemal publicystycznie i szkoda, że nie kojarzą się czytelnikowi z problemem badawczym, ale uważna lektura rozdziału przeczy tej konstatacji.

Również kolejny IV rozdział Miejsce obywateli w państwie uważam za wartościowy. Autor dokonał analizy wzajemnych stosunków i relacji między obywatelami a państwem w kontekście wolności, praw i obowiązków obywateli wobec państwa oraz zobowiązań państwa wobec obywateli. PSL Piast stał na stanowisku utrzymania gwarantowanych w konstytucji praw. Autor porusza także inne powinności państwa, np. kwestię oświaty dla chłopów, ale ten wątek powinien się znaleźć w osobnym rozdziale wraz z problematyką kultury narodowej i kultury chłopskiej, a także jej roli i znaczenia w procesie kulturotwórczym kultury plebejskiej (i nie tylko) w państwie.

Można się zgodzić z autorem, że problematyka mniejszości narodowych, które stanowiły około 1/3 mieszkańców RP, to szczególnie ważny obszar dociekań ludowców, zważywszy na bardzo różnorodny stosunek mniejszości do Polski i instytucji państwowych. Ale czy wszystkie mniejszości narodowe, które aspirowały „do współrządzenia, były lojalne wobec państwa”, np. Ukraińcy? (s. 243). Brakuje w tej części pogłębionej analizy o postawach mniejszości ukraińskiej, a wzmianki w prasie ludowej o zbrodniach popełnionych np. w 1924 r. na Wołyniu to przecież zwiastun kolejnych pogromów na polskich osadnikach i narastania nacjonalizmu ukraińskiego. Czytelnik nie dowie się, jaki był stosunek Piasta do nacjonalistów ukraińskich, którzy w dokumencie programowym uchwalonym w czasie I Kongresu OUN w 1929 r. zapowiedzieli utworzenie państwa ukraińskiego i „,całkowite usunięcie wszystkich »zajmańców« z ziem ukraińskich" [Poliszuk 1997: 75]. Problem ten nie miał znaczenia akcydentalnego, zważywszy na antypolski stosunek wielu środowisk ukraińskich działających w II RP i wydających wówczas 116 tytułów prasy ukraińskiej. 
Rozdział V Wizja ustroju gospodarczego zawiera cenną refleksję dotyczącą wizji ładu gospodarczego w państwie, propozycji rozwiązań systemowych, procedur i mechanizmów „regulujących działalność ludzi i instytucji” (s. 246). Rozdział ten ma wartość źródłotwórczą i faktograficzną, gdyż dotyczy m.in. form własności środków produkcji, ich znaczenia w życiu gospodarczym państwa, wizji rozwoju rolnictwa, przemysłu, rzemiosła i handlu oraz polityki finansowej (s. 245-300). Tę część pracy oparto na różnorodnych źródłach: archiwalnych, programach partii, rezolucjach, prasie i literaturze naukowej. Autor umiejętnie kontroluje i z pozycji metateoretycznej, i źródłowej tok narracji, ale w tak założonym obszarze tematycznym ważnym uzupełnieniem byłoby wykorzystanie kilku jeszcze opracowań i syntez [Kwiatkowski 1928; Klarner 1937; Zieliński 1982; Landau, Tomaszewski 1981; Albert 1995].

W tym obszarze tematycznym daje się zauważyć brak analizy i ocen związanych z kryzysem gospodarczym w 1929 r., który dotknął drobnotowarowe rolnictwo w Polsce. Dalsze zaś rozwarstwienie i rozdarcie „nożyc cen” spowodowało spadek cen na artykuły rolne i pogłębiło pauperyzację ludności wiejskiej. Pojawia się zatem pytanie: czy w prasie PSL Piast podejmowano problematykę kryzysu gospodarczego i jeśli tak, to w jakim zakresie? Czytelnik z pewnością zauważy, iż problematyką gospodarczą partia interesowała się zasadniczo do 1926/1927 r. Jak zatem kryzys gospodarczy wpłynął na lansowaną przez Piast reformę rolną? Pomimo moich pytań i supozycji ten trudny rozdział uważam za szczególnie wartościowy w strukturze pracy.

Ostatni rozdział Bezpieczeństwo państwa jest ważny i nader aktualny, zważywszy na poruszoną problematykę. Dobrze, że autor nie przyjął struktury przymiotnikowej i nie pisał w obowiązującej aktualnie manierze, np. o bezpieczeństwie państwowym czy narodowym, społecznym, ekonomicznym, militarnym czy ujęciu geopolitycznym [np. Zięba 1997]. Rozwaga i roztropność powstrzymała autora od tak szczegółowego ujęcia. Bezpieczeństwo w praktyce, jak również teorii było i jest nadal pojęciem wieloznacznym, wielopłaszczyznowym, trudnym do precyzyjnego definiowania, o czym świadczy wielość definicji. W tym wypadku mamy do czynienia z procesem dynamicznym, a zarysowana struktura ostatniego rozdziału jest prawidłowa. Należy zatem zgodzić się z tezą autora, że wypracowanie optymalnych strategii bezpieczeństwa państwa zależy „od spójności warstw społecznych i ich identyfikacji z Polską”, a zwłaszcza potencjału ekonomiczno-gospodarczego państwa, silnej armii, poprawnych stosunków z sąsiadami, właściwych sojuszy i współuczestniczenia państwa w systemie zbiorowego bezpieczeństwa.

W przypadku II Rzeczypospolitej, która była państwem niejednolitym narodowo (a przeważali w nim chłopi) i, jak zauważył autor, obrona i zapewnienie bezpieczeństwa państwa byłoby możliwe wówczas, gdyby chłopi ,zamach na granice państwa potrakt[owali] jako atak na [ich] własne interesy” (s. 309). W myśli politycznej PSL Piast bezpieczeństwo łączyło się wówczas z moralnością narodu, gospodarką, stabilizacją stosunków społeczno-politycznych, rozwojem sił zbrojnych w kraju (s. 311). Aby skutecznie bronić granic i suwerenności RP, ludowcy z Piasta proponowali ściślejsze zintegrowanie mniejszości narodowych z państwem polskim. Jednocześnie postulowali, aby bezpieczeństwo powiązać z bieżącą sytuacją gospodarczą w kraju i nie kryli obaw, że konflikty społeczne, np. strajki, mogą destabilizować sytuację w państwie. Ten element programu wydaje się mieć głębsze znaczenie i dobrze, że autor dostrzegł jego znaczenie w systemie bezpieczeństwa państwa.

Ogólnie rozdział oceniam pozytywnie (podobnie jak całą monografię), a solidna baza źródłowa i bibliograficzna wykorzystana w pracy wskazuje, że autor wykazuje dobrą orientację w tym zakresie. Program Piasta, jaki został przeanalizowany w kontekście związków przyczynowo-skutkowych, uwarunkowań historycznych, bieżącej sytuacji międzynarodowej zawierał 
wiele oryginalnych postulatów. Konstatacja, że „o sile wewnętrznej państwa” decydowały różne czynniki, np. reforma rolna i konieczność złagodzenia konfliktów społecznych, które naruszały fundamenty państwa, są może interesujące, ale zbyt ogólnikowe.

Autor recenzowanej pracy dostrzegła znaczenie strategii i taktyki, jaką stosował PSL Piast, choć tego nie uwypuklił ze zrozumiałych względów. Umiejętnie powiązał wizję stronnictwa z rozwojem państwa, gospodarki, potrzebą modernizacji różnych jej segmentów oraz z doraźnymi oczekiwaniami i wyzwaniami nie tylko chłopów. W książce dostrzegamy solidny warsztat naukowy, o czym pośrednio świadczą rozbudowane przypisy bibliograficzne i narracyjne. Szkoda, że nie zdecydował się na polemiczne uwagi, zwłaszcza że niekiedy autorzy opracowań, na jakie się powołuje, nie zawsze mają rację.

W pracy zdarzają się drobne potknięcia stylistyczne, ale praca jest napisana dobrą polszczyzną, a logiczny układ pracy wskazuje na umiejętne posługiwanie się językiem naukowym. Na podkreślenie zasługuje podejście utylitarne, ale jednocześnie i poznawcze, które pozostają w układzie „,podwójnej zależności”. Reasumując, otrzymaliśmy pracę solidną, dobrze napisaną, która może być wzorcem i inspiracją dla kolejnych badaczy. Można mieć tylko nadzieję, że będzie ona długo w obiegu informacji naukowej.

\section{BIBLIOGRAFIA}

Albert, A. 1995. Najnowsza historia Polski 1914-1993, t. 1, 1914-1945, Świat Książki, Warszawa.

Chwistek, L. (b.r.w.). Granice nauki. Zarys logiki i metodologii nauk ścistych, Książnica Atlas.

Dobrzański, D. 1999. Interpretacja jako proces nadawania znaczeń, Instytut Filozofii Uniwersytetu Adama Mickiewicza, Poznań.

Gajda, S. 1992. Komunikacja językowa w nauce, a kultura językowa uczonych, [w:] Modele komunikacji międzyludzkiej, W. Woźniakowski (red.), Wydawnictwo Uniwersytetu Warszawskiego, Warszawa.

Holzer, J. 1974. Mozaika polityczna II Rzeczypospolitej, Wydawnictwo Książka i Wiedza, Warszawa.

Jevons, S. 1936. Logika, Cz. Znamierowski (tłum.), „Nasza Księgarnia”, Warszawa.

Juchnowski, J., Sielezin, J.R. 2013. The Concept of State and Nation in Polish Political Thought in the Period of War and Occupation (1918-1939), vol. II, Wydawnictwo Adam Marszałek, Torun.

Kisielewicz, A. 2017. Logika i argumentacja. Praktyczny kurs krytycznego myślenia, Wydawnictwo Naukowe PWN, Warszawa.

Klarner, Cz. 1937. Dochód spoleczny wsi i miast w Polsce w okresie przesilenia gospodarczego 1929-1936, Polskie Towarzystwo Ekonomiczne we Lwowie, Lwów.

Kwiatkowski, E. 1928. Postęp gospodarczy Polski, wyd. II, nakładem tygodnika „Przemysł i Handel”, Warszawa.

Landau, Z., Tomaszewski, J. 1995. Zarys historii gospodarczej Polski 1918-1939, Książka i Wiedza, Warszawa.

Paruch, W. 1999. Myśl polityczna - refleksje metodologiczne o pojęciu, „Annales Universitatis Mariae Curie-Skłodowska, Sectio K: Politologia”, vol. VI, s. 27-39.

Pawłowski, T. 1978. Tworzenie pojęć i definiowanie w naukach humanistycznych, Państwowe Wydawnictwo Naukowe PWN, Warszawa.

Poliszczuk, W. 1997. Legal and Political Assessment of the OUN and UPA - Ocena polityczna i prawna OUN I UPA, Poliszczuk, Toronto 1997.

Sielezin, J.R. 2012. Koncepcje $i$ spory programowe opozycji politycznej w Polsce $w$ latach 1976-1982, Wydawnictwo Uniwersytetu Wrocławskiego, Wrocław. 
Sielezin, J.R. 2018. Wieloznaczność pojęcia , fakt” jako wyznacznik przedmiotu badań w naukach społecznych i humanistycznych, [w:] Studia metodologiczne z nauk spolecznych, J.R. Sielezin (red.), Oficyna Wydawnicza Arboretum, Wrocław, s. 97-129.

Sokal, A.D., Briemont, J. 2004. Modne bzdury. O nadużywaniu pojęć z zakresu nauk ścislych przez postmodernistycznych intelektualistów, Pruszyński i S-ka, Warszawa.

Stankiewicz, W. 1963. Konflikty społeczne na wsi polskiej 1918-1920, Państwowe Wydawnictwo Naukowe PWN, Warszawa.

Such, J. 1975. Problemy wersyfikacji wiedzy. Studium metodologiczne, Państwowe Wydawnictwo Naukowe PWN, Warszawa.

Szaflik, J.R. 1970. Polskie Stronnictwo Ludowe Piast 1926-1931, Ludowa Spółdzielnia Wydawnicza, Warszawa.

Topolski, J. 1984. Metodologia historii, Państwowe Wydawnictwo Naukowe PWN, Warszawa.

Wierciński, A. 2004. O nijaczeniu języka, Wydawnictwo Instytut Śląski, Opole.

Zieliński, H. 1982. Historia Polski 1914-1939, Ossolineum, Wrocław.

Zięba, R. 1997. Kategoria bezpieczeństwa w nauce o stosunkach międzynarodowych, [w:] Bezpieczeństwo narodowe i międzynarodowe u schytku XX wieku, D.B. Bobrow, E. Haliżak, R. Zięba (red.), Wydawnictwo Naukowe Scholar, Warszawa.

Żabko-Potopowicz, A. 1935. Przyczynek do sprecyzowania pojęcia agraryzm, „Agronomia Społeczna i Szkolnictwo Rolnicze", nr 4, s. 56-62.

Żabko-Potopowicz, A. 1937. Agraryzm, [w:] Encyklopedia nauk politycznych (zagadnienia społeczne, polityczne i gospodarcze), t. 1, E.J. Reyman (red.), Wydawnictwo Instytutu Społecznego i Instytutu Wydawniczego „Biblioteka Polska” w Warszawie, Warszawa. 